\title{
Norms of valence and arousal for 14,031 Spanish words
}

\author{
Hans Stadthagen-Gonzalez ${ }^{1}$ - Constance Imbault ${ }^{2}$ Miguel A. Pérez Sánchez ${ }^{3}$. \\ Marc Brysbaert ${ }^{4}$
}

Published online: 5 February 2016

(C) Psychonomic Society, Inc. 2016

\begin{abstract}
Most current models of research on emotion recognize valence (how pleasant a stimulus is) and arousal (the level of activation or intensity that a stimulus elicits) as important components in the classification of affective experiences (Barrett, 1998; Kuppens, Tuerlinckx, Russell, \& Barrett, 2012). Here we present a set of norms for valence and arousal for a very large set of Spanish words, including items from a variety of frequencies, semantic categories, and parts of speech, including a subset of conjugated verbs. In this regard, we found that there were significant but very small differences between the ratings for conjugations of the same verb, validating the practice of applying the ratings for infinitives to all derived forms of the verb. Our norms show a high degree of reliability and are strongly correlated with those of Redondo, Fraga, Padrón, and Comesaña's (2007) Spanish version of the influential Affective Norms for English Words (Bradley \& Lang, 1999), as well as those from Warriner, Kuperman, and Brysbaert (2013), the largest available set of emotional norms for English words. Additionally, we included measures of word prevalence - that is, the percentage of participants that knew a particular word - for each variable (Keuleers, Stevens,
\end{abstract}

Electronic supplementary material The online version of this article (doi:10.3758/s13428-015-0700-2) contains supplementary material, which is available to authorized users.

Hans Stadthagen-Gonzalez

H.Stadthagen@usm.edu

1 Department of Psychology, University of Southern Mississippi, 730 East Beach Blvd., Long Beach, MS 39560, USA

2 McMaster University, Hamilton, Ontario, Canada

3 Universidad de Murcia, Murcia, Spain

4 Ghent University, Ghent, Belgium
Mandera, \& Brysbaert, 2015). Our large set of norms in Spanish not only will facilitate the creation of stimuli and the analysis of texts in that language, but also will be useful for cross-language comparisons and research on emotional aspects of bilingualism. The norms can be downloaded and available as a supplementary materials to this article.

Keywords Valence $\cdot$ Arousal $\cdot$ Emotion $\cdot$ Conjugated verbs

Since very early on in research on emotion, valence and arousal have been central to the classification of affective experiences (Osgood, Suci, \& Tannenbaum, 1957; Wundt, 1912/1924). Valence is a subjective assessment that describes how pleasant a stimulus is (ranging from pleasant to unpleasant), whereas arousal refers to the subjective level of activation or intensity that a stimulus elicits (ranging from quiet to active). Although there is no absolute consensus about the basic components of affect (e.g., Barrett \& Russell, 1999; Fontaine, Scherer, Roesch, \& Ellsworth, 2007; Lang, 1995; Larsen \& Diener, 1992; Reisenzein, 1994; Russell, 1980; Thayer, 1989; Watson \& Tellegen, 1985), most current models recognize valence and arousal as fundamental axes of that construct (Barrett, 1998; Kuppens, Tuerlinckx, Russell, \& Barrett, 2012). The dimensional model of emotions originally proposed by Wundt includes, along with valence and arousal, a third variable: dominance, a subjective assessment of how "in control" a word makes you feel. However, this third variable has not been widely used in the literature (Montefinese, Ambrosini, Fairfield, \& Mammarella, 2014), is not a strong predictor of the variance of affective judgments (Bradley \& Lang, 1994; Lang, Bradley, \& Cuthbert, 2008), and is strongly correlated with valence (Warriner, Kuperman, \& Brysbaert, 2013). 
In addition to their importance in the study of emotion itself, affective variables have been shown to play an important role in multiple areas of cognition; for example, they influence lexical processing (e.g., Kanske \& Kotz, 2007; Kousta, Vinson, \& Vigliocco, 2009; Kuchinke, Võ, Hofmann, \& Jacobs, 2007; Kuperman, Estes, Brysbaert, \& Warriner, 2014; Ortigue et al., 2004; Scott, O'Donnell, Leuthold, \& Sereno, 2009; Syssau \& Laxén, 2012), they affect recall in both short-term memory (Majerus \& D'Argembeau, 2011; Mammarella, Borella, Carretti, Leonardi, \& Fairfield, 2013; Monnier \& Syssau, 2008) and long-term memory (Dewhurst \& Parry, 2000; Kensinger \& Corkin, 2003; Talmi \& Moscovitch, 2004), and they modulate attention effects (Mathewson, Arnell, \& Mansfield, 2008; Stormark, Nordby, \& Hugdahl, 1995). The interest in the effects of emotional properties on language processing goes beyond single words, with several studies having looked into their effect on the morpho-syntactic processing of sentences. For example, Hinojosa et al. (2014) proposed that words with negative content can facilitate the processing of gender agreement violations (at least in the early stages of processing). Similarly, Martín-Loeches et al. (2012) found evidence that the valence of adjectives modulated how sentences are processed at both the syntactic and semantic levels, but Díaz-Lago, Fraga, and Acuña-Fariña (2015) did not find an interaction in the processing of grammatical and emotional properties of words embedded within sentences.

Valence and arousal are, by their very nature, subjective characteristics that reflect experiences and associations with particular objects, events, and words. Values for these variables are usually collected via subjective ratings: Participants are exposed to different stimuli (usually lists of words) and are asked to state how happy or sad, how active or quiet, each stimulus makes them feel. Probably the most influential set of affective norms is Bradley and Lang's (1999) Affective Norms for English Words (ANEW). In ANEW, participants provided their ratings on the basis of the Self-Assessment Manikin (SAM), a nonverbal scale that depicts humanoid figures representing different values along each emotional dimension. Although this method has been widely used in several replications of ANEW, Warriner et al. (2013) showed that equivalent normed data can be obtained by using verbal anchors on a numerical scale.

Norms of the affective properties of words have been published in multiple languages, such as European Portuguese (Soares, Comesaña, Pinheiro, Simões, \& Frade, 2012), Brazilian Portuguese (Kristensen, de Azevedo Gomes, Justo, \& Vieira, 2011), French (Bonin et al., 2003; Gilet, Grühn, Studer, \& Labouvie-Vief, 2012; Monnier \& Syssau, 2013, among others), German (Kanske \& Kotz, 2010; Lahl, Göritz, Pietrowsky, \& Rosenberg, 2009; Võ et al., 2009; Võ, Jacobs, \& Conrad, 2006), Polish (Imbir, 2015), Finnish (Eilola \& Havelka, 2010; Söderholm, Häyry, Laine, \& Karrasch, 2013), Italian (Montefinese, Ambrosini, Fairfield, \& Mammarella, 2014), and Dutch (Moors et al., 2013). In
Spanish, the largest set of emotional norms so far was published in Redondo, Fraga, Padrón, and Comesaña (2007), which includes valence, arousal, and dominance norms for the Spanish translation equivalents of the original 1,034 items from ANEW using a method very similar to that in Bradley and Lang (1999). Similarly, Ferré, Guasch, Moldovan, and Sánchez-Casas (2012) also used Bradley and Lang's SAM to obtain valence and arousal norms for 380 words belonging to three semantic categories - namely, animals, people, and objects. Hinojosa et al.'s (2015) "Madrid Affective Database for Spanish" represents an interesting development, in that it includes not only norms for arousal and valence for 875 words, but also ratings for five discrete emotional categories-happiness, anger, sadness, fear, and disgust-thus allowing a more fine-grained study of the emotional properties of words. Hinojosa et al. also included a useful table listing the details of most previous sets of norms of affective characteristics in various languages.

The availability of compatible norms in several languages not only opens the possibility of conducting relevant research in that particular language, but also allows for cross-language comparison studies (Campos \& Astorga, 1988; Harris, Ayçiçegi, \& Gleason, 2003; Russell, 1991); such norms are useful in the study of how bilingualism affects processing, whether in terms of lexical variables or of the expression of emotion (e.g., Altarriba \& Canary, 2004; Opitz \& Degner, 2012). Research in these areas is very active and has yielded interesting results for both bilingualism and the study of emotions. For example, there is evidence that in bilinguals, the activation of emotion is modulated by their level of proficiency in each language (Degner, Doycheva, \& Wentura, 2011; Robinson \& Altarriba, 2015). Bilinguals often report that emotional words carry a higher level of intensity in their first (or dominant) language, particularly regarding taboo or swear words (e.g., Dewaele, 2004; Pavlenko, 2012), a difference also observed with measures of autonomic response (e.g., Colbeck \& Bowers, 2012; Harris et al., 2003). On the other hand, there is evidence that when a bilingual is highly proficient in both languages, equivalent emotional activation is found in the two languages, even for late bilinguals (e.g., Eilola, Havelka, \& Sharma, 2007). Also, some crosslinguistic differences may relate to emotion words. For example, some recent work (e.g., Kazanas \& Altarriba, 2015) has investigated the distinction between emotion words (e.g., joy/ anger) and emotion-laden words (e.g., puppy/coffin). The authors found that in English, emotion-word processing occurs more quickly than emotion-laden word processing, especially for positive words. However, this effect seems to be less robust in Spanish. Research on the relationship between emotional words and bilingualism also encompasses other areas of cognition, such as memory. For example, is has been shown that recall is better for emotional words than for neutral words in monolingual speakers (e.g., Kensinger \& Corkin, 2003; LaBar \& 
Phelps, 1998; MacKay \& Ahmetzanov, 2005), but there is a debate as to whether that advantage is also present for the second language of a bilingual. Anooshian and Hertel (1994) did not find such advantage, whereas Ayçiçegi and Harris (2004) found that, under certain circumstances, the effect was even larger in the second language. As can be seen, the literature on bilingual processing of emotional words encompasses many different topics and is far from settled, so much remains to be done in that regard. What all these studies have in common is the need for information on the emotional characteristics of large sets of words in multiple languages. Large sets of emotional norms are necessary in order to create well-controlled item sets in experimental studies, as well as for input in regression and other types of analysis.

In most of the norming studies mentioned before, the numbers of items have ranged from a few hundred to just over a thousand. Recent years have seen the publication of larger sets of norms of different lexical characteristics, usually including several thousand words (e.g., Brysbaert, Stevens, De Deyne, Voorspoels, \& Storms, 2014; Kuperman, StadthagenGonzalez, \& Brysbaert, 2012; Warriner et al., 2013). The availability of such large norm databases has greatly facilitated the creation of stimulus sets, as well as making it possible to include such variables in the automated analysis of text samples (Leveau, Jhean-Larose, Denhière, \& Nguyen, 2012).

In addition, large data sets make it possible to study the relationship between the affective properties of words and other lexical or semantic variables. Warriner et al. (2013), for instance, reported that positive words have a higher frequency than negative words. They related this finding to the observation that the English language has a bias toward positivity or pro-social benevolent communication interactions (see also Warriner \& Kuperman, 2015). The relationship between word frequency and arousal has tended to be negative (high-frequency words are rated, on average, as calmer), although this overall relationship hid the fact that some of the high-frequency words were very arousing (such as love, god, life, money, hell, kill, fuck, happy). Children seem to be taught positive, low-arousing words first, since there is a negative correlation between age of acquisition (AoA) and valence, together with a positive correlation between AoA and arousal. Finally, Warriner et al. reported that positive words tended to refer to concepts with high imageability.

In these large norming studies, data have tended to be collected in a modular fashion, dividing up the stimulus list into blocks that can be rated in a single session, and introducing interrater reliability measures to allow for the integration of the blocks into a single list. This approach allows for the collection of ratings for very large word lists. So far the biggest set of affective word norms for English is Warriner et al. (2013), which provides ratings for valence, arousal, and dominance for nearly 14,000 words. Our purpose in the present study was to generate a set of norms for a comparable number of Spanish words, using procedures very similar to those of Warriner et al. Our large database will also allow us to explore how valence and arousal ratings relate to each other and to other lexical variables - namely frequency, AoA, familiarity, imageability, and concreteness - that are available in Spanish for large sets of words. Warriner et al. found weak correlations between emotional variables and most lexical variables included in their analyses, but found interesting relationships between their emotional ratings and the above-mentioned lexical characteristics.

An additional objective was to evaluate whether affective properties such as valence and arousal are fully determined by the lemma of a word. A morphologically rich language such as Spanish allows us to evaluate whether, for example, verb conjugations modify the affective properties of the infinitive form. As was noted by Rivera, Bates, Orozco-Figueroa, and Wicha (2010), very few lexical databases include information for inflected verbs. Warriner et al.'s (2013) emotional norms included only infinitive verbs, on the assumption that emotional values generalize to inflected forms, but so far this assumption has not been empirically tested. Moreover, whereas English verbs undergo little inflection, in languages with morphologically rich inflections such as Spanish, infinitives can be quite different from their conjugated forms. We were interested in whether there are differences in emotional ratings with regard to person (first vs. third) and tense (present, future, and conditional). With regard to person, our interest arose in view of the literature on self-referential processing of emotional words (e.g., Fossati et al., 2003; Northoff et al., 2006), which points to differences in the processing of emotional words when they are framed as personal attributes of the participant versus of another person. With regard to verb tense, we were interested in whether differences in ratings would emerge between present (ongoing, immediate actions), future (certain but unfulfilled actions), and conditional (potential actions). It is also possible that such differences, if they exist, only emerge in the presence of larger differences in word form - that is, for irregular verbs - so we looked into that contrast as well. Determining whether different verb conjugations share rating values is important for two reasons: (1) to determine the extent to which emotional ratings are dependent on the word form or are shared by variations of a base word (a "lemma"), and more pragmatically, (2) to determine whether it is necessary to include conjugated forms in these types of ratings, or whether infinitives are enough.

\section{Method}

\section{Participants}

A total of 512 native speakers of Spanish took part in our study. All respondents were taking undergraduate psychology 
courses at the University of Murcia, Spain, and received extra credit for their participation. Participants had the choice to rate up to three "blocks" of words per variable, and to provide ratings for one or both variables (ratings for arousal were collected at least 11 weeks after those for valence). A total of 233 participants rated words for both valence and arousal, whereas the rest only did so for one or the other variable. Valence ratings were obtained from 350 raters (of which 294 , or $80 \%$, were female); of those, $79 \%$ completed three blocks of ratings, $9 \%$ two blocks, and $12 \%$ one block. The raters for valence had an average age of 22 years 3 months (range $=18$ to 62 years, $S D=6$ years 1 month). Arousal ratings were obtained from 395 raters (of which 327, or $82.7 \%$, were female); of those, $56 \%$ completed three blocks of ratings, $21 \%$ two blocks, and $23 \%$ one block. The raters for arousal had an average age of 22 years 5 months (range = 18 to 62 years, $S D=5$ years 8 months). The dominance of female participants is in line with current practice in psychological experiments and is acceptable, given the high correlation of the valence and arousal ratings provided by males and females (Montefinese et al., 2014; Moors et al., 2013). Still, it is fair to say that the present data may not be the most optimal to predict the responses of an all-male participant group. ${ }^{1}$

\section{Materials}

The 14,037 words included in this set of norms were assembled from four sources (with some items being present in more than one source): (1) First, we used all 1,034 words from the adaptation of the ANEW norms to Spanish by Redondo, Fraga, Padrón, and Comesaña (2007). These words were used as "controls" for validation purposes. (2) In order to include words from a variety of semantic categories, we included 3, 509 words from Marful, Díez, and Fernandez (2014), a Spanish adaptation of Battig and Montague (1969). In that study, participants were asked to write as many words as they could for 56 semantic categories. For our word list, we included all words with an availability of 0.7 or more and excluded proper nouns (male and female), geographical names (provinces, countries, and cities), and institutional names (colleges and brands). If both singular and plural were present in the list, only the singular form was included. If only the plural was present, the plural form was included. (3) To explore the extent to which conjugated forms share emotional ratings with their infinitive form, a sample of 104 verbs were added. The list included regular verbs with all three infinitive terminations (-ar, -er, and -ir), as well as irregular verbs. We took care not to include verbs with conjugations that could also be a different part of speech (e.g., juego is both the conjugated verb "I play" and the noun "game"). For each verb, we included its

\footnotetext{
${ }^{1}$ A comparison between the genders was not indicated for our study, since some ratings were provided by only four male participants.
}

infinitive form as well as the following conjugations: present indicative first person, present indicative third person (which is also the first person imperative for regular verbs), conditional (first and third person share the same word form), and future first person, for a total of 520 words. (4) The rest of the words $(8,974)$ were taken from EsPal (Duchon, Perea, SebastiánGallés, Martí, \& Carreiras, 2013), a Spanish database that provides information about many lexical properties based on a very large corpus. In order to include content words with a variety of grammatical functions, we included words with at least one count per million in EsPal's individual listings of verbs, nouns, adjectives, and adverbs (excluding adverbs ending in -mente, the equivalent of "-ly" in English). Many of the words included in this list can function as more than one part of speech (e.g., the same word form can be both a verb and a noun), but taking into account just the most frequent part-ofspeech category for each word according to EsPal, our list had the following composition: nouns $=61.8 \%$, adjectives $=$ $21.3 \%$, verbs $=15.8 \%$, adverbs $=0.7 \%$, determiners $=$ $0.2 \%$, and pronouns $=0.1 \%$. An effort was made to eliminate foreign words, proper nouns, acronyms, and multiword utterances from the list. In terms of frequency, the average Zipf value (van Heuven, Mandera, Keuleers, \& Brysbaert, 2014) of the set, according to EsPal, was $3.65(S D=0.73$, range $=0.51$ to 7.46 , median $=3.58$ ). This means that our stimuli are nicely centered in the frequency range (Zipf values of $0-3$ indicate low-frequency words, and values of 4-7, high-frequency words).

\section{Procedure}

The stimuli were distributed across 43 blocks with between 351 and 354 words each. Each block consisted of nine calibrator words, 41 control words from Redondo et al.'s (2007) Spanish adaptation of ANEW, and a random selection of the other words in the list. The calibrators consisted of three each of verbs, adjectives, and nouns, spanning the full range of the scale in the Redondo et al. norms. Different sets of calibrators were chosen for valence and arousal and presented at the beginning of each block, in order to give participants a sense of the entire range of the stimuli that they would encounter. The calibrators for valence were (in ascending order of valence): sangriento ("bloody"), funeral ("funeral"), contaminar ("to pollute"), mendigo ("beggar), afectar ("to affect"), martillo ("hammer"), liso ("smooth"), mejorar ("to improve"), and alegre ("happy"). The calibrators for arousal were (in ascending order of valence): dormir ("to sleep"), silla ("chair"), nublado ("cloudy"), árbol ("tree"), ahorrar ("to save money"), insecto ("insect"), capaz ("able"), guapo ("handsome"), and ganar ("to win"). Control words were randomly interspersed with the other words on the list and used to assess the reliability of our ratings with regard to the Redondo et al. norms. The sets of control words could appear in more than 
Table 1 Words with the highest and lowest valence and arousal ratings

\begin{tabular}{llll}
\hline Spanish Word & English Translation & Valence Rating & Arousal Rating \\
\hline Relajado & Relaxed & 7.48 & 1.40 \\
Atentado & Attack & 1.85 & 8.45 \\
Entierro & Burial & 1.15 & 7.35 \\
Libre & Free & 8.85 & 3.73 \\
\hline
\end{tabular}

one block, and they were similar but not identical for the valence and arousal blocks. All words in a block (except the calibrators) were randomized once and presented in the same order to each participant rating that block.

Each block was rated by 20 participants. Blocks with ratings that correlated with the mean ratings per items at less than .10 were removed and replaced with ratings from a different participant $(2.7 \%$ of the collected blocks; 26 blocks for valence, 20 blocks for arousal). These changes are already reflected in the participant information provided above.

Participants accessed the blocks online through Qualtrics. They first completed a brief demographic questionnaire and were then given written instructions for the relevant variable. The instructions given were similar to those of the ANEW norms; the exact wording in Spanish and an English translation are provided in the Appendix. Most participants rated each block in $30 \mathrm{~min}$ or less. Participants were asked to rate each word on a 9-point scale, as follows: valence from $1=$ infeliz ("unhappy") to $9=$ feliz ("happy"), and arousal from $1=\operatorname{tranquilo(a)~("quiet")~to~} 9=\operatorname{exitado}(a)$ ("excited"). There was a further option to indicate that they did not know the word (No conozco la palabra). Following Redondo et al. (2007), the direction of the scales was reversed from those used in ANEW, a change intended to make the rating process more intuitive to participants. Each screen displayed approximately 24 words, and the scale ( 1 to 9 ) and anchors (infelizfeliz, tranquilo-excitado) were displayed at the top of each group of six words. Following Warriner et al. (2013), we decided not to include the SAMs that had been used in the ANEW study and other similar norms; in the "Results and

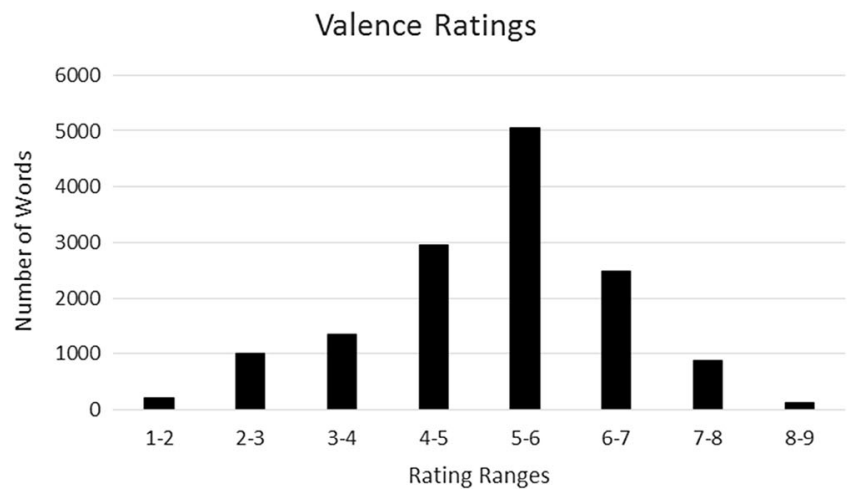

Fig. 1 Distribution of ratings for valence and arousal discussion" section, we show that our numerical ratings correlated highly with the SAM ratings from ANEW.

\section{Results and discussion}

For valence, only 222 words were rated less than ten times, and $3.2 \%$ of the responses were removed due to participants not recognizing the word. For arousal, only 183 words were rated less than ten times, and $3.5 \%$ of the responses were removed due to participants not recognizing the word.

Both valence and arousal were positively skewed, with respective average ratings of $5.2(S D=1.27)$ and $5.3(S D=$ 1.50) that exceeded the midpoint of the measurement scale (refer to Table 1 for the valence and arousal extremes). This finding is consistent with other rating studies (Warriner et al., 2013) and, for valence, supports the bias toward positive word types that is well-established in other languages (cf. Warriner \& Kuperman, 2015). Histograms for the distributions of ratings for valence and arousal are shown in Fig. 1. The valence ratings had a larger range than did arousal; the average valence ratings ranged from 1.1 to 8.8 , whereas the average arousal ratings ranged from 1.4 to 8.4 . The ratings for both valence and arousal were relatively consistent across participants ( $S D$ s $=1.27$ and 1.50 , respectively) when compared to other norming studies of valence and arousal ( $S D \mathrm{~s}=1.68$ and 2.30, respectively; Warriner et al., 2013).

The valence ratings were relatively stable across the valence spectrum (Fig. 2, left panel), whereas the variance in the arousal ratings was highest in the lowest-arousal words and decreased linearly as arousal increased (Fig. 2, right panel).

Figure 3 shows the relationship between valence and arousal. As had been seen in previous studies (e.g., Warriner et al., 2013), the two variables had a U-shaped relationship; very positive and very negative words were highly arousing, whereas neutral words were less arousing $\left(R^{2}=.314, p<\right.$ $.001)$.

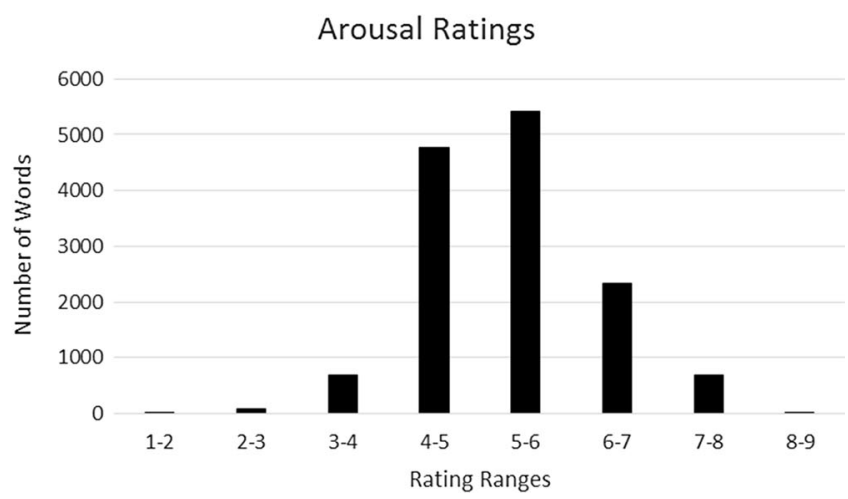




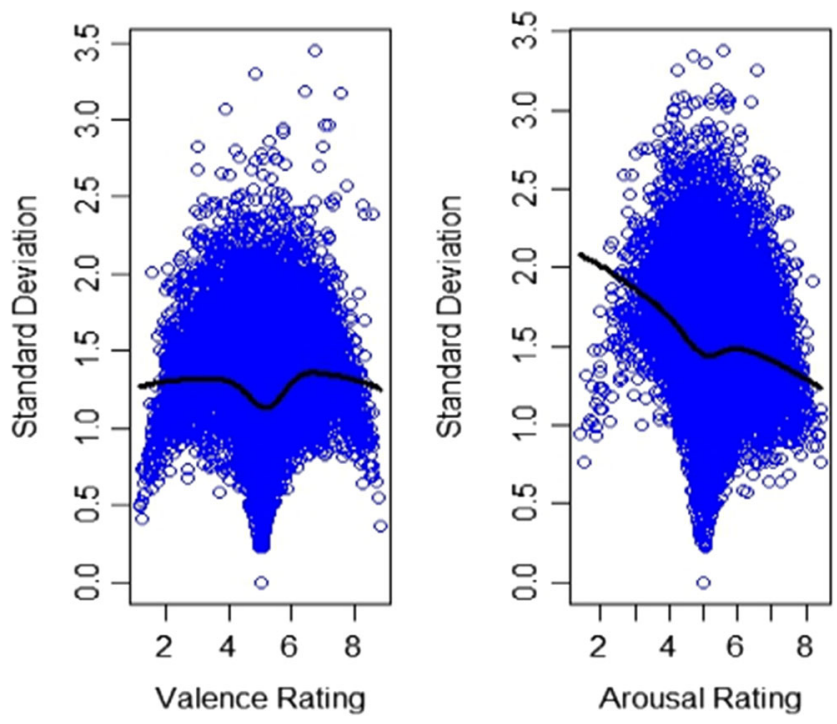

Fig. 2 Average standard deviations (variance among responders) across the valence and arousal ranges

To test whether the correlations with frequency, AoA, and imageability reported by Warriner et al. (2013) for the English language also hold for Spanish, we made use of the word frequency data as well as the subjective ratings for familiarity, imageability, and concreteness reported by Duchon et al. (2013), and the AoA ratings reported by Alonso, Fernandez, and Diez (2015). In general, our data showed the same patterns as those reported by Warriner et al. (2013; see also Montefinese et al., 2014). As the frequency, familiarity,

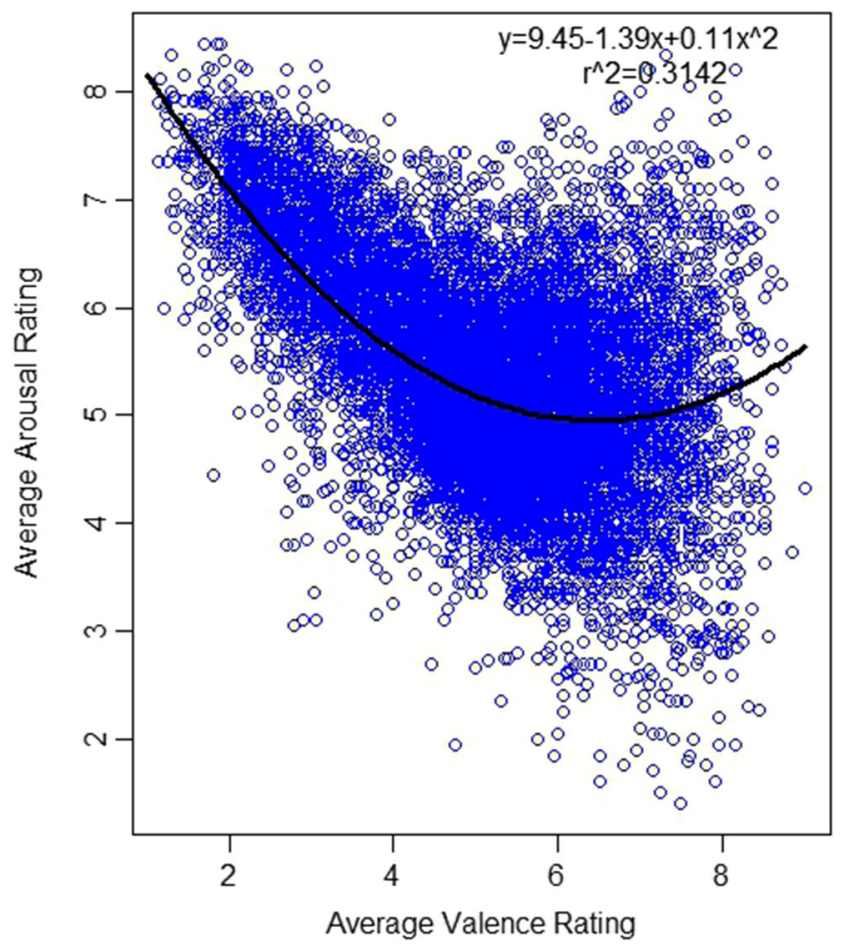

Fig. 3 Average valence and arousal ratings per word, plotted with the quadratic best fit imageability, or concreteness of a word increased, the valence rating of that word increased, but the arousal rating decreased. One could speculate that this was due to the "familiarity" or "mere exposure" effect, which has been shown in multiple domains: Frequent exposure to a particular stimulus leads to more positive evaluations of it (Bornstein \& Craver-Lemley, 2004; Murphy \& Zajonc, 1993; Zajonc, 1968, 2001, among many others; see also Bornstein, 1989, for a meta-analysis). Along the same lines, frequent items could be taken as being more commonplace, and therefore less exciting or arousing. This trend was reversed when looking at AoA: Words that were learned earlier in life resulted in higher valence ratings and lower arousal ratings. Words learned later in life were more arousing and more negative (see Fig. 4 for plots, and Table 2 for correlations). An explanation could be that children are shielded from "unpleasant" words, such as taboo words and insults, which are only acquired later in life, or at least that people norming words for AoA tend to believe so when they provide their ratings.

\section{Reliability of our norms}

In order to determine the reliability of our methods, we split the participants randomly into two groups and calculated their mean ratings for each word. After recording the correlations between these two groups of participants, we performed this task another 99 times to get a set of 99 correlations. The mean correlation coefficient provided us with the measure of splithalf reliability, which for valence amounted to .88 (.87 and $.89,95 \%$ confidence interval) and for arousal amounted to .75 (.73 and $.76,95 \%$ confidence interval), suggesting that our methods were highly reliable.

\section{Comparison with other norms}

Our norms were highly correlated to other Spanish word ratings, including Hinojosa et al. (2015) (for 636 words in common: $r=.97, p<.001$, and $r=.71, p<.001$, respectively, for valence and arousal) and Redondo et al. (2007; for 1,031 words in common: $r=.98, p<.001$, and $r=.75, p<.001$, respectively, for valence and arousal). We translated the words of our list into English ${ }^{2}$ and found 9,403 one-word translation equivalents in common with Warriner et al.'s (2013) list. Previous studies (e.g., Eilola \& Havelka, 2010; Montefinese et al., 2014; Redondo et al., 2007; Soares et al., 2012; Warriner et al., 2013) have shown that ratings for both valence and arousal are relatively consistent across languages, a finding confirmed by the strong correlation between our Spanish norms and Warriner et al.'s English norms $(r=.79, p<.001$, and $r=.54, p<.001$, respectively, for valence and arousal).

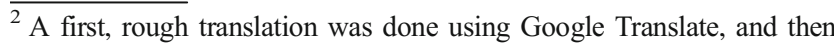
checked word by word by hand for accuracy.
} 

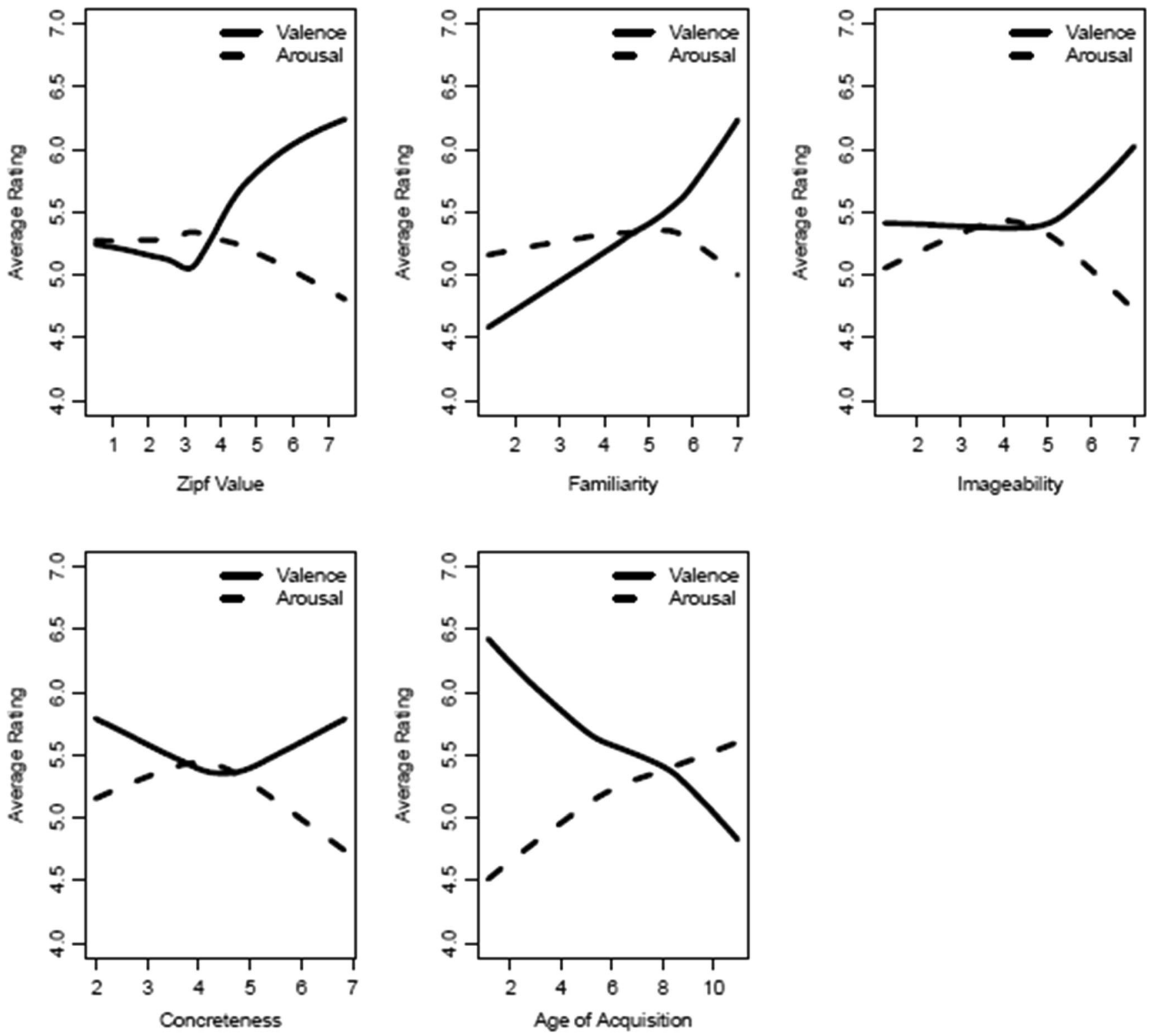

Fig. 4 Average frequency $(n=13,932)$, familiarity $(n=5,280)$, imageability $(n=5,118)$, concreteness $(n=5,296)$, and age of acquisition $(n=5,081)$ across the valence and arousal spectra. The word frequencies used to calculate the Zipf value, as well as the

subjective ratings for familiarity, imageability, and concreteness, were obtained from EsPal (Duchon et al., 2013), whereas the age-ofacquisition ratings came from Alonso et al. (2015)

Table 2 Correlations between word characteristics and their arousal and valence

\begin{tabular}{lll}
\hline & Arousal & Valence \\
\hline Frequency (Zipf value; $n=13,932)$ & $-.042, p<.001$ & $.163, p<.001$ \\
Familiarity $(n=5,280)$ & $-.029, p=.032$ & $.176, p<.001$ \\
Imageability $(n=5,118)$ & $-.084, p<.001$ & $.062, p<.001$ \\
Concreteness $(n=5,296)$ & $-.127, p<.001$ & $.020, p=.142$ \\
AoA $(n=5,081)$ & $.184, p<.001$ & $-.189, p<.001$
\end{tabular}

The word frequencies used to calculate the Zipf value, as well as the subjective ratings for familiarity, imageability, and concreteness were obtained from EsPal (Duchon et al., 2013), and AoA ratings came from Alonso, Fernandez, and Diez (2015)

\section{Conjugated verbs}

In Spanish, syntactic information about a word is often expressed in inflectional morphemes added to the word stem (similarly to the suffix "-s" in the English verb "walks," indicating the third person singular). We examined several word forms of Spanish verbs to test whether the syntactic characteristics of verbal tense, person, mode, or aspect systematically affect emotional responses to verbal word forms. As can be seen in Table 3, there were no differences between the first and third person ratings for either valence or arousal. This seems to indicate that the differences between first and second person 
Table 3 Comparisons between each tense (reporting mean $\pm S E$ and paired two-sample $t$ tests)

\begin{tabular}{|c|c|c|}
\hline Comparison & Valence & Arousal \\
\hline $\begin{array}{l}\text { 1st person present vs. } 3 \mathrm{rd} \\
\text { person present }\end{array}$ & $\begin{array}{l}5.33 \pm 0.136 \text { and } 5.38 \pm 0.144 ; n=101, t=-0.281, d f= \\
\quad 100, p=.7791\end{array}$ & $\begin{array}{l}5.32 \pm 0.080 \text { and } 5.38 \pm 0.10 ; n=101, t=-1.11, d f=100, p \\
\quad=.385\end{array}$ \\
\hline $\begin{array}{l}\text { Future tense vs. conditional } \\
\text { tense }\end{array}$ & $\begin{array}{l}5.33 \pm 0.15 \text { and } 5.09 \pm 0.13 ; n=98, t=-4.11, d f=97, p< \\
\quad .001, \text { Cohen's } d=0.172\end{array}$ & $\begin{array}{l}5.72 \pm 0.07 \text { and } 5.54 \pm 0.074 ; n=98, t=2.52, d f=97, p< \\
.001, \text { Cohen's } d=0.149\end{array}$ \\
\hline $\begin{array}{l}\text { Present (1st and 3rd) vs. future } \\
\text { tense }\end{array}$ & $\begin{array}{l}5.34 \pm 0.14 \text { and } 5.33 \pm 0.15 ; n=98, t=0.131, d f=97, p= \\
\quad .896\end{array}$ & $\begin{array}{l}5.36 \pm 0.086 \text { and } 5.72 \pm 0.07 ; n=98, t=-6.78, d f=97, p< \\
\quad .001, \text { Cohen's } d=0.451\end{array}$ \\
\hline $\begin{array}{l}\text { Present }(1 \mathrm{st} \text { and } 3 \mathrm{rd}) \mathrm{vs} . \\
\text { conditional tense }\end{array}$ & $\begin{array}{l}5.34 \pm 0.14 \text { and } 5.12 \pm 0.13 ; n=98, t=3.08, d f=97, p= \\
.00281, \text { Cohen's } d=0.167\end{array}$ & $\begin{array}{l}5.36 \pm 0.086 \text { and } 5.54 \pm 0.074 ; n=98, t=-3.78, d f=97, p \\
\quad<.001, \text { Cohen's } d=0.223\end{array}$ \\
\hline 1st person vs. infinitive form & $\begin{array}{l}5.33 \pm 0.13 \text { and } 5.52 \pm 0.17 ; n=102, t=-2.96, d f=101, p \\
\quad=.00386, \text { Cohen's } d=0.121\end{array}$ & $\begin{array}{l}5.32 \pm 0.08 \text { and } 5.55 \pm 0.10 ; n=102, t=-4.26, d f=101, p \\
\quad<.001, \text { Cohen's } d=0.25\end{array}$ \\
\hline 3rd person vs. infinitive form & $\begin{array}{l}5.38 \pm 0.14 \text { and } 5.52 \pm 0.17 ; n=101, t=-2.12, d f=100, p \\
\quad=.0364, \text { Cohen's } d=0.0857\end{array}$ & $\begin{array}{l}5.38 \pm 0.10 \text { and } 5.55 \pm 0.10 ; n=101, t=-3.03, d f=100, p \\
\quad=.00312, \text { Cohen's } d=0.171\end{array}$ \\
\hline Future vs. infinitive form & $\begin{array}{l}5.34 \pm 0.15 \text { and } 5.52 \pm 0.17 ; n=101, t=-2.85, d f=100, p \\
\quad=.00526, \text { Cohen's } d=0.113\end{array}$ & $\begin{array}{l}5.72 \pm 0.07 \text { and } 5.56 \pm 0.10 ; n=101, t=2.62, d f=100, p= \\
.0101, \text { Cohen's } d=0.180\end{array}$ \\
\hline Conditional vs. infinitive form & $\begin{array}{l}5.09 \pm 0.13 \text { and } 5.51 \pm 0.18 ; n=98, t=-5.22, d f=97, p< \\
\quad .001, \text { Cohen's } d=0.274\end{array}$ & $\begin{array}{l}5.54 \pm 0.07 \text { and } 5.56 \pm 0.10 ; n=98, t=-0.353, d f=97, p= \\
\quad .725\end{array}$ \\
\hline
\end{tabular}

found for self-referential processing of emotional words using other paradigms (e.g., Fossati et al., 2003; Northoff et al., 2006) are not captured by subjective ratings such as the ones presented here. Furthermore, despite the fact that most of the other differences between conjugated verb forms were significant, the size of such differences was in all cases very small (a maximum of $4.7 \%$ of the 9-point scale for valence, and $4.0 \%$ for arousal). Tables 4 and 5 show the words with the largest difference between the different conjugations for valence and arousal, respectively.
It is possible that differences between the emotional ratings of different verb conjugations would be more marked for irregular verbs, since the differences between word forms are larger. However, when we compared ratings for just the irregular verbs in our set $(n=58)$, we obtained results similar to those from before (see Table 6): Several differences were significant, but they were very small in magnitude (less than $6.6 \%$ of the scale for valence, and less than $6.3 \%$ for arousal). Taken together, and given the small variations between the different conjugations, these results indicate that it is generally

Table 4 Words with the biggest difference in valence between conjugations

\begin{tabular}{|c|c|c|c|c|}
\hline & Spanish Lemma & English Lemma & Spanish Conjugation & English Conjugation \\
\hline 1st person present vs. 3 rd person present & Leer & To Read & $\begin{array}{l}\text { Leo }(5.55) \\
\text { Lee }(7.50)\end{array}$ & $\begin{array}{l}\text { I read } \\
\text { He/She reads }\end{array}$ \\
\hline Future tense vs. conditional tense & Alcanzar & To Reach & $\begin{array}{l}\text { Alcanzaré (7.55) } \\
\text { Alcanzaría (5.65) }\end{array}$ & $\begin{array}{l}\text { I will reach } \\
\text { I would reach }\end{array}$ \\
\hline Present (1st and 3rd) vs. future tense & Conseguir & To get & $\begin{array}{l}\text { Consigo }(6.50) \\
\text { Consigue }(6.65) \\
\text { Consiguiré }(8.00)\end{array}$ & $\begin{array}{l}\text { I get } \\
\text { He/She gets } \\
\text { I will get }\end{array}$ \\
\hline Present (1st and 3 rd) vs. conditional tense & Ofender & To offend & $\begin{array}{l}\text { Ofendo }(2.63) \\
\text { Ofende }(2.05) \\
\text { Ofendería }(3.90)\end{array}$ & $\begin{array}{l}\text { I offend } \\
\text { He/She offends } \\
\text { I would offend }\end{array}$ \\
\hline 1st person vs. infinitive form & Comer & To eat & $\begin{array}{l}\text { Cómo }(5.75) \\
\text { Comer (7.44) }\end{array}$ & $\begin{array}{l}\text { I eat } \\
\text { To eat }\end{array}$ \\
\hline 3rd person vs. infinitive form & Resentir & To resent & $\begin{array}{l}\text { Resiente (4.47) } \\
\text { Resentir (2.90) }\end{array}$ & $\begin{array}{l}\text { He/She resents } \\
\text { To resent }\end{array}$ \\
\hline Future vs. infinitive form & Pensar & To think & $\begin{array}{l}\text { Pensaré (5.65) } \\
\text { Pensar (7.30) }\end{array}$ & $\begin{array}{l}\text { I will think } \\
\text { To think }\end{array}$ \\
\hline Conditional vs. infinitive form & Sentir & To feel & $\begin{array}{l}\text { Sentiría }(5.80) \\
\text { Sentir }(7.95)\end{array}$ & $\begin{array}{l}\text { I would feel } \\
\text { To feel }\end{array}$ \\
\hline
\end{tabular}


Table 5 Words with the biggest difference in arousal between conjugations

\begin{tabular}{|c|c|c|c|c|}
\hline & Spanish Lemma & English Lemma & Spanish Conjugation & English Conjugation \\
\hline 1 st person present vs. 3 rd person present & Creer & To believe & $\begin{array}{l}\text { Creo }(5.20) \\
\text { Cree }(3.85)\end{array}$ & $\begin{array}{l}\text { I believe } \\
\text { He/she believes }\end{array}$ \\
\hline Future tense vs. conditional tense & Imaginar & To imagine & $\begin{array}{l}\text { Imaginaré (6.10) } \\
\text { Imaginaría ( } 4.60)\end{array}$ & $\begin{array}{l}\text { I will imagine } \\
\text { I would imagine }\end{array}$ \\
\hline Present (1st and 3rd) vs. future tense & Sentir & To know & $\begin{array}{l}\text { Siento }(4.80) \\
\text { Siente }(3.70) \\
\text { Sentiré }(6.10)\end{array}$ & $\begin{array}{l}\text { I know } \\
\text { He/she knows } \\
\text { I would know }\end{array}$ \\
\hline Present (1st and 3rd) vs. conditional tense & Escribir & To write & $\begin{array}{l}\text { Escribo }(4.40) \\
\text { Escribe }(4.10) \\
\text { Escrbiría(5.500) }\end{array}$ & $\begin{array}{l}\text { I write } \\
\text { He/she writes } \\
\text { I would write }\end{array}$ \\
\hline 1st person vs. infinitive form & Conocer & To know & $\begin{array}{l}\text { Conozco }(4.25) \\
\text { Conocer }(6.00)\end{array}$ & $\begin{array}{l}\text { I know } \\
\text { To know }\end{array}$ \\
\hline 3rd person vs. infinitive form & Sentir & To feel & $\begin{array}{l}\text { Siente }(3.70) \\
\text { Sentir }(5.45)\end{array}$ & $\begin{array}{l}\mathrm{He} / \text { she feels } \\
\text { To feel }\end{array}$ \\
\hline Future vs. infinitive form & Inspirar & To inspire & $\begin{array}{l}\text { Inspiraré (5.80) } \\
\text { Inspirar (4.125) }\end{array}$ & $\begin{array}{l}\text { I will inspire } \\
\text { To inspire }\end{array}$ \\
\hline Conditional vs. infinitive form & Saber & To know & $\begin{array}{l}\text { Sabría (5.84) } \\
\text { Saber (4.25) }\end{array}$ & $\begin{array}{l}\text { I would know } \\
\text { To know }\end{array}$ \\
\hline
\end{tabular}

safe to assume that emotional ratings for infinitive verbs can be applied to their inflected forms.

\section{Availability of the norms}

The full set of norms is available in a comma-separated (.csv) file as supplementary materials to this article. The words are organized alphabetically, and the headings for the table are as follows: ValenceMean = mean valence value for all valid responses, ValenceSD = standard deviation of the valence ratings, \%ValenceRaters $=$ number of participants who knew and rated the word for valence, ArousalMean = mean arousal value for all valid responses, ArousalSD $=$ standard deviation of the arousal ratings, and \%ArousalRaters = number of participants who knew and rated the word for arousal. \%ValenceRaters and \%ArousalRaters are included as measures of word prevalence, which has been shown to be a strong predictor of reaction times in lexical decision (Keuleers, Stevens, Mandera, \& Brysbaert, 2015). We also

Table 6 Comparisons between each tense of irregular verbs (reporting mean $\pm S E$ and paired two-sample $t$ tests)

\begin{tabular}{|c|c|c|}
\hline Comparison & Valence & Arousal \\
\hline $\begin{array}{l}\text { 1st person present vs. } 3 \text { rd } \\
\text { person present }\end{array}$ & $\begin{array}{l}5.57 \pm 0.15 \text { and } 5.57 \pm 0.15 ; n=58, t=0.155, d f=57, p= \\
.877\end{array}$ & $\begin{array}{l}5.07 \pm 0.094 \text { and } 5.13 \pm 0.12 ; n=58, t=-0.9127, d f=57, p \\
\quad=.420\end{array}$ \\
\hline $\begin{array}{l}\text { Future tense vs. conditional } \\
\text { tense }\end{array}$ & $\begin{array}{l}5.48 \pm 0.18 \text { and } 5.23 \pm 0.13 ; n=56, t=3.06, d f=55, p< \\
\quad .01, \text { Cohen's } d=0.218\end{array}$ & $\begin{array}{l}5.58 \pm 0.095 \text { and } 5.35 \pm 0.087 ; n=56, t=3.62, d f=55, p< \\
\quad .001, \text { Cohen's } d=0.346\end{array}$ \\
\hline $\begin{array}{l}\text { Present (1st and } 3 \mathrm{rd}) \mathrm{vs.} \\
\quad \text { future tense }\end{array}$ & $\begin{array}{l}5.57 \pm 0.15 \text { and } 5.46 \pm 0.17 ; n=58, t=1.66, d f=57, p= \\
\quad .102\end{array}$ & $\begin{array}{l}5.01 \pm 0.099 \text { and } 5.58 \pm 0.091 ; n=58, t=-7.19, d f=57, p< \\
\quad .001, \text { Cohen's } d=0.663\end{array}$ \\
\hline $\begin{array}{l}\text { Present }(1 \text { st and } 3 \mathrm{rd}) \mathrm{vs} . \\
\text { conditional tense }\end{array}$ & $\begin{array}{l}5.59 \pm 0.15 \text { and } 5.23 \pm 0.13 ; n=58, t=5.66, d f=57, p< \\
\quad .001, \text { Cohen's } d=0.346\end{array}$ & $\begin{array}{l}5.10 \pm 0.10 \text { and } 5.35 \pm 0.087 ; n=56, t=-4.52, d f=57, p< \\
\quad .001, \text { Cohen's } d=0.348\end{array}$ \\
\hline 1st person vs. infinitive form & $\begin{array}{l}5.57 \pm 0.15 \text { and } 5.81 \pm 0.20 ; n=58, t=-3.10, d f=57, p< \\
\quad .01, \text { Cohen's } d=0.191\end{array}$ & $\begin{array}{l}5.07 \pm 0.094 \text { and } 5.28 \pm 0.12 ; ; n=58, t=-2.83, d f=57, p< \\
\quad .01, \text { Cohen's } d=0.26\end{array}$ \\
\hline 3rd person vs. infinitive form & $\begin{array}{l}5.58 \pm 0.15 \text { and } 5.82 \pm 0.19 ; n=58, t=-2.58, d f=57, p< \\
\quad .05, \text { Cohen's } d=0.187\end{array}$ & $\begin{array}{l}5.13 \pm 0.12 \text { and } 5.28 \pm 0.12 ; n=58, t=-1.78, d f=57, p= \\
\quad .080\end{array}$ \\
\hline Future vs. infinitive form & $\begin{array}{l}5.46 \pm 0.17 \text { and } 5.81 \pm 0.19 ; n=58, t=-4.13, d f=57, p< \\
\quad .001, \text { Cohen's } d=0.260\end{array}$ & $\begin{array}{l}5.58 \pm 0.095 \text { and } 5.28 \pm 0.12 ; n=58, t=4.101, d f=57, p< \\
\quad .001, \text { Cohen's } d=0.373\end{array}$ \\
\hline $\begin{array}{l}\text { Conditional vs. infinitive } \\
\text { form }\end{array}$ & $\begin{array}{l}5.23 \pm 0.13 \text { and } 5.82 \pm 0.20 ; n=58, t=-5.47, d f=57, p< \\
\quad .001, \text { Cohen's } d=0.480\end{array}$ & $\begin{array}{l}5.35 \pm 0.22 \text { and } 5.28 \pm 0.087 ; n=56, t=0.886, d f=57, p= \\
\quad .378\end{array}$ \\
\hline
\end{tabular}


indicate each word's dominant part of speech according to EsPal (Duchon et al., 2013). Ninety-five of the words do not have an entry in EsPal, so their parts of speech were determined manually. Entries with less than ten raters in either or both variables are marked with an asterisk.

\section{General discussion}

In summary, the present article expands on the work of Redondo et al. (2007) by providing valence and arousal ratings for over 14,000 Spanish words, greatly increasing the availability of items normed on those variables. We were able to collect such a large set of norms by using a modular approach, and we have shown that our norms are reliable and compatible with previous, similar studies. We also showed that there is little variation in ratings for different conjugations of the same verb. The availability of such a large set of norms will not only be useful for opening up research opportunities in Spanish by helping in the creation of stimulus sets, correlational studies, and text analyses, but its compatibility with the Warriner et al. (2013) norms and others will also be of value for research on emotional aspects of bilingualism, translation studies, and cross-language research.

\section{Appendix}

\section{Instructions for VALENCE in Spanish (Adapted from Warriner et al., 2013)}

\section{AGRADABILIDAD:}

Te invitamos a participar en este estudio sobre las emociones y cómo la gente responde a diferentes tipos palabras. Usarás una escala para indicar cómo te sientes mientras lees cada palabra. La escala que usarás va desde

1 = "Infeliz" hasta 9 = "Feliz."

A un extremo de la escala estás completamente infeliz, molesto(a), insatisfecho(a), melancólico(a), o desesperado(a). Cuando una palabra te haga sentir infeliz debes indicarlo seleccionando el 1.

El otro extremo de la escala es cuando te sientes feliz, alegre, satisfecho(a), contento(a), o esperanzado(a). Puedes indicar el sentirte completamente feliz al leer una palabra seleccionando el 9. Los valores en la escala también te permiten describir sentimientos intermedios de bienestar seleccionando cualquier otro sentimiento. Si te sientes completamente neutral al leer una palabra, ni feliz ni triste, escoge el medio de la escala (el número 5).

Por favor responde rápidamente y no pases mucho tiempo pensando en cada palabra.
Es mejor que hagas tus valoraciones basándote en tu primera reacción inmediata mientras lees cada palabra.

\section{English translation of the instructions for VALENCE}

\section{VALENCE:}

We invite you to take part in the study about emotions and how people how people respond to different types of words.

You will use a scale to rate how you felt while reading each word. The scale ranges from

1 "Unhappy" to 9 "Happy."

At one extreme of the scale, you are completely unhappy, annoyed, unsatisfied, melancholic, despaired, or bored. When a word makes you feel unhappy you should indicate it by selecting 1 .

The other end of the scale is for when you feel happy, pleased, satisfied, contented, or hopeful. You can indicate feeling completely happy when you read a word by selecting 9 .

The numbers on the scale also allow you to describe intermediate feelings of pleasure by selecting any other feeling.

If you feel completely neutral when you read a word, neither happy nor sad, select the middle of the scale (number 5).

Please work at a rapid pace and don't spend too much time thinking about each word.

It's better if you base your ratings on your immediate reaction while you read each word.

\section{Instructions for AROUSAL in Spanish}

\section{ACTIVACIÓN:}

Te invitamos a participar en este estudio sobre las emociones y cómo la gente responde a diferentes tipos palabras.

Usarás una escala para indicar cómo te sientes mientras lees cada palabra.

La escala que usarás va desde

$1=$ "tranquilo(a)" hasta $9=$ "excitado(a)."

A un extremo de la escala estás relajado(a), tranquilo(a), aletargado(a), aburrido(a), soñoliento(a), o desactivado(a). Cuando una palabra te haga sentir completamente tranquilo(a) debes indicarlo seleccionando el 1.

El otro extremo de la escala es cuando te sientes completamente estimulado(a), excitado(a), frenético(a), nervioso(a), completamente despierto(a) o activado(a). Puedes indicar el sentirte excitado(a) al leer una palabra seleccionando el 9.

Los valores en la escala también te permiten describir sentimientos intermedios de tranquilidad/excitación seleccionando cualquier otro sentimiento.

Si te sientes completamente neutral al leer una palabra, ni excitado(a) ni completamente tranquilo(a), escoge el medio de la escala (el número 5) 
Por favor responde rápidamente y no pases mucho tiempo pensando en cada palabra.

Es mejor que hagas tus valoraciones basándote en tu primera reacción inmediata mientras lees cada palabra.

\section{English translation of the instructions for AROUSAL}

\section{AROUSAL:}

We invite you to take part in the study about emotions and how people how people respond to different types of words.

You will use a scale to rate how you felt while reading each word. The scale ranges from

1 "Calm" to 9 "Excited."

At one extreme of the scale, you are completely relaxed, calm, sluggish, dull, sleepy, or unaroused. When a word makes you feel totally calm you should indicate it by selecting 1 .

The other end of the scale is for when you feel stimulated, excited, frenzied, jittery, wide-awake, or aroused. You can indicate feeling excited when you read a word by selecting 9 .

The numbers on the scale also allow you to describe intermediate feelings of calmness/arousal by selecting any other feeling.

If you feel completely neutral when you read a word, neither excited nor totally calm, select the middle of the scale (number 5).

Please work at a rapid pace and don't spend too much time thinking about each word.

It's better if you base your ratings on your immediate reaction while you read each word.

\section{References}

Alonso, M. A., Fernandez, A., \& Diez, E. (2015). Subjective age-ofacquisition norms for 7,039 Spanish words. Behavior Research Methods, 47, 268-274. doi:10.3758/s13428-014-0454-2

Altarriba, J., \& Canary, T. M. (2004). The influence of emotional arousal on affective priming in monolingual and bilingual speakers. Journal of Multilingual and Multicultural Development, 25, 248-265. doi: 10.1080/01434630408666531

Anooshian, L. J., \& Hertel, P. T. (1994). Emotionality in free recall: Language specificity in bilingual memory. Cognition and Emotion, 8, 503-514. doi:10.1080/02699939408408956

Ayçiçegi, A., \& Harris, C. (2004). Bilinguals' recall and recognition of emotion words. Cognition and Emotion, 18, 977-987. doi:10.1080/ 02699930341000301

Barrett, L. F. (1998). Discrete emotions or dimensions? The role of valence focus and arousal focus. Cognition and Emotion, 12, 579-599. doi: $10.1080 / 026999398379574$

Barrett, L. F., \& Russell, J. A. (1999). The structure of current affect: Controversies and emerging consensus. Current Directions in Psychological Science, 15, 79-85. doi:10.1111/1467-8721.00003

Battig, W. F., \& Montague, W. E. (1969). Category norms for verbal items in 56 categories: A replication and extension of the Connecticut norms. Journal of Experimental Psychology, 80, 1-46. doi:10. 1037/h0027577
Bonin, P., Méot, A., Aubert, L., Malardier, N., Niedenthal, P., \& CapelleToczek, M.-C. (2003). Normes de concrétude, de valeur d'imagerie, de fréquence subjective et de valence émotionnelle pour 866 mots. L'Année Psychologique, 104, 655-694. doi:10.3406/psy.2003. 29658

Bornstein, R. F. (1989). Exposure and affect: Overview and meta-analysis of research, 1968-1987. Psychological Bulletin, 106, 265-289. doi: 10.1037/0033-2909.106.2.265

Bornstein, R. F., \& Craver-Lemley, C. (2004). Mere exposure effect. In R. F. Pohl (Ed.), Cognitive illusions: A handbook on fallacies and biases in thinking, judgement and memory (pp. 215-234). Hove: Psychology Press.

Bradley, M. M., \& Lang, P. J. (1994). Measuring emotion: The SelfAssessment Manikin and the semantic differential. Journal of Behavior Therapy and Experimental Psychiatry, 25, 49-59. doi: 10.1016/0005-7916(94)90063-9

Bradley, M. M., \& Lang, P. J. (1999). Affective norms for English words (ANEW): Stimuli, instruction manual and affective ratings (Technical Report No. C-1). Gainesville: University of Florida, NIMH Center for Research in Psychophysiology.

Brysbaert, M., Stevens, M., De Deyne, S., Voorspoels, W., \& Storms, G. (2014). Norms of age of acquisition and concreteness for 30,000 Dutch words. Acta Psychologica, 150, 80-84. doi:10.1016/j. actpsy.2014.04.010

Campos, A., \& Astorga, V. M. (1988). Abstractness and emotional values for French and Spanish words. Perceptual and Motor Skills, 66, 649-650. doi:10.2466/pms.1988.66.2.649

Colbeck, K. L., \& Bowers, J. S. (2012). Blinded by taboo words in L1 but not L2. Emotion, 12, 217-222. doi:10.1037/a0026387

Degner, J., Doycheva, C., \& Wentura, D. (2011). It matters how much you talk: On the automaticity of affective connotations of first and second language words. Bilingualism: Language and Cognition, 15, 181-189. doi:10.1017/S1366728911000095

Dewaele, J. M. (2004). The emotional force of swearwords and taboo words in the speech of multilinguals. Journal of Multilingual and Multicultural Development, 25, 204-222. doi:10.1080/ 01434630408666529

Dewhurst, S. A., \& Parry, L. A. (2000). Emotionality, distinctiveness and recollective experience. European Journal of Cognitive Psychology, 12, 541-551. doi:10.1080/095414400750050222

Díaz-Lago, M., Fraga, I., \& Acuña-Fariña, C. (2015). Time course of gender agreement violations containing emotional words. Journal of Neurolinguistics, 36, 79-93. doi:10.1016/j.jneuroling.2015.07. 001

Duchon, A., Perea, M., Sebastián-Gallés, N., Martí, A., \& Carreiras, M. (2013). EsPal: One-stop shopping for Spanish word properties. Behavior Research Methods, 45, 1246-1258. doi:10.3758/s13428013-0326-1

Eilola, T. M., \& Havelka, J. (2010). Affective norms for 210 British English and Finnish nouns. Behavior Research Methods, 42, 134 140. doi:10.3758/BRM.42.1.134

Eilola, T.M., Havelka, J., Sharma, D. (2007) . Emotional activation in the first and second language. Cognition \& Emotion, 21, 1064-1076. doi:10.1080/02699930601054109

Ferré, P., Guasch, M., Moldovan, C., \& Sánchez-Casas, R. (2012). Affective norms for 380 Spanish words belonging to three different semantic categories. Behavior Research Methods, 44, 395-403. doi: 10.3758/s13428-011-0165-x

Fontaine, J. R. J., Scherer, K. R., Roesch, E. B., \& Ellsworth, P. C. (2007). The world of emotions is not two-dimensional. Psychological Science, 18, 1050-1057. doi:10.1111/j.1467-9280.2007.02024.x

Fossati, P., Hevenor, S. J., Graham, S. J., Grady, C., Keightley, M. L., Craik, F., \& Mayberg, H. (2003). In search of the emotional self: An fMRI study using positive and negative emotional words. American Journal of Psychiatry, 160, 1938-1945. doi:10.1176/appi.ajp.160. 11.1938 
Gilet, A. L., Grühn, D. D., Studer, J. J., \& Labouvie-Vief, G. G. (2012). Valence, arousal, and imagery ratings for 835 French attributes by young, middle-aged, and older adults: The French Emotional Evaluation List (FEEL). European Review of Applied Psychology, 62, 173-181. doi:10.1016/j.erap.2012.03.003

Harris, C. L., Ayçiçegi, A., \& Gleason, J. B. (2003). Taboo words and reprimands elicit greater autonomic reactivity in a first language than in a second language. Applied Psycholinguistics, 24, 561-579. doi: $10.1017 / \mathrm{S} 0142716403000286$

Hinojosa, J. A., Albert, J., Fernández-Folgueiras, U., Santaniello, G., López-Bachiller, C., Sebastián, M., Sánchez-Carmona, A.J., Pozo, M. A. (2014). Effects of negative content on the processing of gender information: An event-related potential study. Cognitive, Affective, \& Behavioral Neuroscience, 14, 1286-1299. doi:10. 3758/s13415-014-0291-x

Hinojosa, J. A., Martínez-García, N., Villalba-García, C., FernándezFolgueiras, U., Sánchez-Carmona, A., Pozo, M. A., \& Montoro, P. R. (2015). Affective norms of 875 Spanish words for five discrete emotional categories and two emotional dimensions. Behavior Research Methods. doi:10.3758/s13428-015-0572-5

Imbir, K. K. (2015). Affective Norms for 1,586 Polish Words (ANPW): Duality-of-mind approach. Behavior Research Methods, 47, 860 870. doi:10.3758/s13428-014-0509-4

Kanske, P., \& Kotz, S. A. (2007). Concreteness in emotional words: ERP evidence from a hemifield study. Brain Research, 1148, 138-148. doi:10.1016/j.brainres.2007.02.044

Kanske, P., \& Kotz, S. A. (2010). Leipzig Affective Norms for German: A reliability study. Behavior Research Methods, 42, 987-991. doi: 10.3758/BRM.42.4.987

Kazanas, S. A., \& Altarriba, J. (2015). Emotion word processing: Effects of word type and valence in Spanish-English bilinguals. Journal of Psycholinguistic Research. doi:10.1007/s10936-015-9357-3

Kensinger, E. A., \& Corkin, S. (2003). Memory enhancement for emotional words: Are emotional words more vividly remembered than neutral words? Memory \& Cognition, 31, 1169-1180. doi:10.3758/ BF03195800

Keuleers, M., Stevens, M., Mandera, P., \& Brysbaert, M. (2015). Word knowledge in the crowd: Measuring vocabulary size and word prevalence in a massive online experiment. Quarterly Journal of Experimental Psychology, 68, 1665-1692. doi:10.1080/17470218. 2015.1022560

Kousta, S. T., Vinson, D. P., \& Vigliocco, G. (2009). Emotion words, regardless of polarity, have a processing advantage over neutral words. Cognition, 112, 473-481. doi:10.1016/j.cognition.2009.06. 007

Kristensen, C. H., de Azevedo Gomes, C. F., Justo, A. R., \& Vieira, K. (2011). Normas brasileiras para o Affective Norms for English Words. Trends in Psychiatry and Psychotherapy, 33, 135-146. doi:10.1590/S2237-60892011000300003

Kuchinke, L., Võ, M. H., Hofmann, M., \& Jacobs, A. M. (2007). Pupillary responses during lexical decisions vary with word frequency but not emotional valence. International Journal of Psychophysiology, 65, 132-140. doi:10.1016/j.ijpsycho.2007.04. 004

Kuperman, V., Estes, Z., Brysbaert, M., \& Warriner, A. B. (2014). Emotion and language: Arousal and valence affect word recognition. Journal of Experimental Psychology: General, 143, 10651081. doi:10.1037/a0035669

Kuperman, V., Stadthagen-Gonzalez, H., \& Brysbaert, M. (2012). Ageof-acquisition ratings for 30 thousand English words. Behavior Research Methods, 44, 978-990. doi:10.3758/s13428-012-0210-4

Kuppens, P., Tuerlinckx, F., Russell, J. A., \& Barrett, L. F. (2012). The relation between valence and arousal in subjective experience. Psychological Bulletin, 139, 917-940. doi:10.1037/a0030811
LaBar, K., \& Phelps, E. (1998). Arousal-mediated memory consolidation: Role of the medial temporal lobe in humans. Psychological Science, 9, 490-493. doi:10.1111/1467-9280.00090

Lahl, O., Göritz, A. S., Pietrowsky, R., \& Rosenberg, J. (2009). Using the World-Wide Web to obtain large-scale word norms: 190,212 ratings on a set of 2,654 German nouns. Behavior Research Methods, 41, 13-19. doi:10.3758/BRM.41.1.13

Lang, P. J. (1995). The emotion probe: Studies of motivation and emotion. American Psychologist, 50, 372-385. doi:10.1037/0003-066X. 50.5.372

Lang, P. J., Bradley, M. M., \& Cuthbert, B. N. (2008). International Affective Picture System (IAPS): Affective ratings of pictures and instruction manual (Technical Report A-8). Gainesville: University of Florida, Center for Research in Psychophysiology.

Larsen, R. J., \& Diener, E. (1992). Promises and problems with the circumplex model of emotion. In M. S. Clark (Ed.), Emotion (Review of Personality and Social Psychology (Vol. 13, pp. 2559). Newbury Park: Sage.

Leveau, N., Jhean-Larose, S., Denhière, G., \& Nguyen, B. L. (2012). Validating an interlingual metanorm for emotional analysis of texts. Behavior Research Methods, 44, 1007-1014. doi:10.3758/s13428012-0208-y

MacKay, D. G., \& Ahmetzanov, M. V. (2005). Emotion, memory, and attention in the taboo Stroop paradigm: An experimental analog of flashbulb memories. Psychological Science, 16, 25-32. doi:10. 1111/j.0956-7976.2005.00776.x

Majerus, S., \& D'Argembeau, A. (2011). Verbal short-term memory reflects the organization of long-term memory: Further evidence from short-term memory for emotional words. Journal of Memory and Language, 64, 181-197. doi:10.1016/j.jml.2010.10.003

Mammarella, N., Borella, E., Carretti, B., Leonardi, G., \& Fairfield, B. (2013). Examining an emotion enhancement effect in working memory: Evidence from age-related differences. Neuropsychological Rehabilitation, 23, 416-428. doi:10.1080/ 09602011.2013.775065

Marful, A., Díez, E., \& Fernandez, A. (2014). Normative data for the 56 categories of Battig and Montague (1969) in Spanish. Behavior Research Methods, 47, 902-910. doi:10.3758/s13428-014-0513-8

Martín-Loeches, M., Fernández, A., Schacht, A., Sommer, W., Casado, P., Jiménez-Ortega, L., \& Fondevila, S. (2012). The influence of emotional words on sentence processing: Electrophysiological and behavioral evidence. Neuropsychologia, 50, 3262-3272. doi:10. 1016/j.neuropsychologia.2012.09.010

Mathewson, K. J., Arnell, K. M., \& Mansfield, C. A. (2008). Capturing and holding attention: The impact of emotional words in rapid serial visual presentation. Memory \& Cognition, 36, 182-200. doi:10. 3758/MC.36.1.182

Monnier, C., \& Syssau, A. (2008). Semantic contribution to verbal short term memory: Are pleasant words easier to remember than neutral words in serial recall and serial recognition? Memory \& Cognition, 36, 35-42. doi:10.3758/MC.36.1.35

Monnier, C., \& Syssau, A. (2013). Affective Norms for French Words (FAN). Behavior Research Methods. doi:10.3758/s13428-0130431-1

Montefinese, M., Ambrosini, E., Fairfield, B., \& Mammarella, N. (2014). The adaptation of the Affective Norms for English Words (ANEW) for Italian. Behavior Research Methods, 46, 887-903. doi:10.3758/ s13428-013-0405-3

Moors, A., De Houwer, J., Hermans, D., Wanmaker, S., van Schie, K., Van Harmelen, A. L., \& Brysbaert, M. (2013). Norms of valence, arousal, dominance, and age of acquisition for 4,300 Dutch words. Behavior Research Methods, 45, 169-177. doi:10.3758/s13428012-0243-8

Murphy, S. T., \& Zajonc, R. B. (1993). Affect, cognition, and awareness: Affective priming with suboptimal and optimal stimulus. Journal of 
Personality and Social Psychology, 64, 723-739. doi:10.1037/ 0022-3514.64.5.723

Northoff, G., Heinzel, A., de Greck, M., Bermpohl, F., Dobrowolny, H., \& Panksepp, J. (2006). Self-referential processing in our brain-A meta-analysis of imaging studies on the self. NeuroImage, 31, 440457. doi:10.1016/j.neuroimage.2005.12.002

Opitz, B., \& Degner, J. (2012). Emotionality in a second language: It's a matter of time. Neuropsychologia, 50, 1961-1967. doi:10.1016/j. neuropsychologia.2012.04.021

Ortigue, S., Michel, C. M., Murray, M. M., Mohr, C., Carbonnel, S., \& Landis, T. (2004). Electrical neuroimaging reveals early generator modulation to emotional words. NeuroImage, 21, 1242-1251. doi: 10.1016/j.neuroimage.2003.11.007

Osgood, C. E., Suci, G. J., \& Tannenbaum, P. H. (1957). The measurement of meaning. Urbana: University of Illinois Press.

Pavlenko, A. (2012). Affective processing in bilingual speakers: Disembodied cognition? International Journal of Psychology, 47, 405-428. doi:10.1080/00207594.2012.743665

Redondo, J., Fraga, I., Padrón, I., \& Comesaña, M. (2007). The Spanish adaptation of ANEW (Affective Norms for English Words). Behavior Research Methods, 39, 600-605. doi:10.1037/00223514.67.3.525

Reisenzein, R. (1994). Pleasure-arousal theory and the intensity of emotions. Journal of Personality and Social Psychology, 67, 525-539. doi:10.1037/0022-3514.67.3.525

Rivera, S. M., Bates, E. A., Orozco-Figueroa, A., \& Wicha, N. Y. Y. (2010). Spoken verb processing in Spanish: An analysis using a new online resource. Applied Psycholinguistics, 31, 29-57. doi:10. 1017/S0142716409990154

Robinson, C. J., \& Altarriba, J. (2015). The interrelationship between emotion, cognition, and bilingualism. In K. Dziubalska-Kołaczyk, J. Weckwerth, M. Marecka, \& M. Gruszecka (Eds.), Yearbook of the Poznan Linguistic Meeting (Vol. 1). Berlin: DeGruyter Open.

Russell, J. A. (1980). A circumplex model of affect. Journal of Personality and Social Psychology, 39, 1161-1178. doi:10.1037/ h0077714

Russell, J. A. (1991). Culture and the categorization of emotions. Psychological Bulletin, 110, 426-450. doi:10.1037/0033-2909. 110.3.426

Scott, G. G., O'Donnell, P. J., Leuthold, H., \& Sereno, S. C. (2009). Early emotion word processing: Evidence from event-related potentials. Biological Psychology, 80, 95-104. doi:10.1016/j.biopsycho.2008. 03.010

Soares, A. P., Comesaña, M., Pinheiro, A. P., Simões, A., \& Frade, C. S. (2012). The adaptation of the Affective Norms for English Words
(ANEW) for European Portuguese. Behavior Research Methods, 44, 256-269. doi:10.3758/s13428-011-0131-7

Söderholm, C., Häyry, E., Laine, M., \& Karrasch, M. (2013). Valence and arousal ratings for 420 Finnish nouns by age and gender. PLoS ONE, 8, e72859. doi:10.1371/journal.pone.0072859

Stormark, K. M., Nordby, H., \& Hugdahl, K. (1995). Attentional shifts to emotionally charged cues-Behavioral and ERP data. Cognition and Emotion, 9, 507-523. doi:10.1080/02699939508408978

Syssau, A., \& Laxén, J. (2012). L'influence de la richesse sémantique dans la reconnaissance visuelle des mots émotionnels. Canadian Journal of Experimental Psychology, 66, 70-78. doi:10.1037/ a0027083

Talmi, D., \& Moscovitch, M. (2004). Can semantic relatedness explain the enhancement of memory for emotional words? Memory \& Cognition, 32, 742-751. doi:10.3758/BF03195864

Thayer, R. E. (1989). The biopsychology of mood and arousal. New York: Oxford University Press.

Van Heuven, W. J. B., Mandera, P., Keuleers, E., \& Brysbaert, M. (2014). Subtlex-UK: A new and improved word frequency database for British English. Quarterly Journal of Experimental Psychology, 67, 1176-1190. doi:10.1080/17470218.2013.850521

Võ, M. L., Conrad, M., Kuchinke, L., Urton, K., Hofmann, M. J., \& Jacobs, A. M. (2009). The Berlin Affective Word List Reloaded (BAWL-R). Behavior Research Methods, 41, 534-538. doi:10. 3758/BRM.41.2.534

Võ, M. L., Jacobs, A. M., \& Conrad, M. (2006). Cross-validating the Berlin Affective Word List. Behavior Research Methods, 38, 606 609. doi:10.3758/BF03193892

Warriner, A. B., \& Kuperman, V. (2015). Affective biases in English are bi-dimensional. Cognition and Emotion, 29, 1147-1167. doi:10. 1080/02699931.2014.968098

Warriner, A. B., Kuperman, V., \& Brysbaert, M. (2013). Norms of valence, arousal, and dominance for 13,915 English lemmas. Behavior Research Methods, 45, 1191-1207. doi:10.3758/ s13428-012-0314-x

Watson, D., \& Tellegen, A. (1985). Toward a consensual structure of mood. Psychological Bulletin, 98, 219-235. doi:10.1037/00332909.98.2.219

Wundt, W. M. (1924). An introduction to psychology (R. Pintner, Trans.). London: Allen \& Unwin (original work published 1912).

Zajonc, R. B. (1968). Attitudinal effects of mere exposure. Journal of Personality and Social Psychology, 9, 1-27. doi:10.1037/h0025848

Zajonc, R. B. (2001). Mere exposure: A gateway to the subliminal. Current Directions in Psychological Science, 10, 224-228. doi:10. $1111 / 1467-8721.00154$ 